\title{
Penerapan Metode Demonstrasi Bermediakan Video Pidato Soekarno Dalam Pembelajaran Berpidato Pada Siswa Kelas X SMA Negeri 1 Lemahabang Cirebon
}

\author{
Nurhannah Widianti ${ }^{1)}$ \\ Pendidikan Bahasa Indonesia Program Pascasarjana Universitas Negeri Semarang
}

\begin{abstract}
Abstrak. Penelitian ini bertujuan menunjukkan keefektifan metode demonstrasi bermediakan pidato Soekarno dalam pembelajaran mengonversi teks eksposisi ke dalam bentuk berpidato pada siswa kelas X SMA Negeri 1 Lemahabang.Metode penelitian yang digunakan, yaitu metode eksperimen dengan desain Nonequivalent Control Group Desain.Artinya, pada desain ini kelompok eksperimen maupun kelompok kontrol tidak dipilih secara random. Dari hasil analisis data dan pembahasan disimpulkan bahwa metode demonstrasi bermediakan pidato Soekarno efektif dalam pembelajaran mengonversi teks eksposisi ke dalam bentuk berpidato. Hal ini dibuktikan oleh hasil tes akhir berpidato siswa eksperimen lebih tinggi dari kelas kontrol yang mempelajari materi berpidato tanpa menerapkan metode demonstrasi bermediakan video pidato Soekarno. Nilai rata-rata tes akhir kelas eksperimen mencapai 79,38, sedangkan nilai rata-rata kelas kontrol hanya 73,38. Sementara itu, perhitungan uji t pun menunjukkan bahwa $t$ hitung $(2,47)>t$ tabel $(1,99)$ pada taraf signifikan $5 \%$ dengan derajat kebebasannya mencapai angka 77. Lalu, hasil uji hipotesis menyatakan bahwa t hitung $(2,73)>\mathrm{t}$ tabel $(1,69)$.
\end{abstract}

Kata kunci: Metode Demonstrasi, Efektivitas, Berpidato

\section{PENDAHULUAN}

Berbicara merupakan salah satu keterampilan berbahasa yang penting dikuasai siswa. Dikatakan demikian karena keterampilan ini berperan sebagai penciri kekomunikatifan secara verbal. Melalui berbicara, sikap, pemikiran, dan gagasan siswa dapat tercermin. Oleh karena itu, berpidato yang termasuk ke dalam keterampilan berbicara di depan umum pun perlu untuk dipelajari siswa. Hal ini dikarenakan pada saat tertentu kecakapan tersebut sangat dibutuhkan dalam kehidupan bermasyarakat. Kegiatan berpidato dibutuhkan dalam berbagai macam kegiatan, contohnya berpidato diperlukan untuk melantik, memperingati hari besar nasional, mengadakan musyawarah organisasi, dan menjalankan kehidupan kenegaraan [7].

Realitasnya, pembelajaran berpidato di sekolah terkadang tidak berjalan sesuai harapan. Hal ini diakibatkan beberapa faktor sebagai berikut. (1) Siswa kurang antusias dalam mengikuti pembelajaran. (2) Siswa mengalami berbagai kendala pada saat berpidato, seperti (penggunaan intonasi kurang tepat, artikulasi kurang jelas, penyampaian pidato tidak runtut, dan kurang menunjukkan gerak-gerik yang sesuai sebagai pembicara). (3) Siswa kurang percaya diri dalam berpidato.

Berdasarkan fenomena tersebut. Penulis mengkaji penerapan metode dalam pembelajaran mengkonversi teks eksposisi kedalam bentuk berpidato dengan judul "Penerapan Metode Demonstrasi Bermediakan Video Pidato Soekarno". Hal ini dilakukan untuk mengatasi permasalahan-permasalahan yang berdampak terhadap proses pembelajaran dan hasil belajar siswadalam berpidato.

Metode demonstrasi merupakan metode belajar yang memperlihatkan cara atau proses untuk melakukan suatu kegiatan secara langsung atau pun tidak langsung. Melalui metode ini, siswa dapat memperhatikan dengan saksama prosedur dan penjelasan lisan yang tepat serta akurat. Tujuannya agar siswa mampu memahami secara menyeluruh antara teori dan praktik. Hingga akhirnya, siswa mampu memperagakan secara optimal suatu keterampilan yang diinginkan oleh tujuan pembelajaran. Metode demonstrasi adalah cara penyajian pelajaran dengan menunjukkan kepada siswa suatu proses, situasi, atau benda tertentu [3]. Baik sebenarnya ataupun melalui tiruan yang sering disertai dengan penjelasan lisan. Melalui metode demonstrasi, proses penerimaan siswa terhadap pelajaran akan lebih berkesan sehingga mampu membentuk pengertian yang baik dan sempurna. Lalu, siswa juga dapat mengamati dan memperhatikan apa yang diperlihatkan selama pelajaran berlangsung.

Metode demonstrasi merupakan pembelajaran yang memberikan pengalaman secara langsung kepada siswa dan membantu siswa untuk memahami materi secara mendalam. Selain itu, metode ini dapat memusatkan perhatian siswa karena objek yang dipelajari divisualisasikan secara nyata untuk diamati dan ditelaah oleh siswa. Sementara itu, adanya media pembelajaran diharapkan mampu menunjang jalannya proses demonstrasi. Namun, penentuan media pembelajaran harus sesuai. Tujuannya agar materi yang dipelajari dapat dipahami dengan baikdan mampu mendongkrak hasil belajar siswa. Manfaat media pembelajaran dalam pembelajaran 
guna menyeragamkan penyampaian materi, memperjelas dan membuat pembelajaran menarik, meningkatkan kualitas hasil belajar, dan mengefesiensikan waktu dan tenaga [2].

Pada hakikatnya, metode demonstrasi mencakup tiga hal, yaitu menunjukkan, mengamati, dan menjelaskan. Melalui tiga komponen tersebut, pembelajaran berpidato dapat dipahami dengan baik. Sementara itu, media pembejaran yang relevan, yaitu video pidato Soekarno akan membuat siswa fokus dan tertarik mengamati proses keterampilan yang dipelajari. Di dalam penerapannya, kolaborasi antara metode dan media pembelajaran ini memungkinkan guru untuk mengeksplorasi pemahaman siswa melalui kegiatan tanya jawab.

\section{METODE}

Dalam penelitian ini penulis menggunakan penelitian eksperimen semu (Nonequivalent Control Group Desain). Menurut Sugiyono (2013:116) pada desain ini kelompok eksperimen maupun kelompok kontrol tidak dipilih secara random [9]. Populasi dalam penelitian ini, yaitu seluruh siswa kelas X SMA Negeri 1 Lemahabang. Sementara itu, sampel penelitian ditentukan menggunakan teknik sampling purposive. Sugiyono (2013: 124) menyatakan bahwa sampling purposive adalah teknik penentuan sampel dengan pertimbangan tertentu. Pada penelitian ini, penulis memutuskan kelas X MIIA 1 dan X MIIA 2 dijadikan sampel karena dua kelas tersebut memiliki kemampuan yang setara dalam keterampilan berbicara.

Adapun instrumen penelitian yang digunakan penulis, yakni tes dan observasi. Tes digunakan untuk mengetahui tingkat prestasi siswa dalam berpidato. Saat tes berpidato siswa perlu memperhatikan faktor kebahasaan (lafal, tekanan, intonasi, tempo) dan faktor nonkebahasaan (sikap dan penampilan, gerak-gerik, penguasaan berpidato, penyampaian struktur berpidato). Lalu, observasi digunakan untuk mengetahui aktivitas guru dan siswa selama proses pembelajaran.Pada kelas eksperimen, penulis memberi perlakuan berupa penerapan metode demonstrasi bermediakan video pidato Soekarno. Sementara itu, kelas kontrol menerapkan metode simulasi.

\section{HASIL DAN PEMBAHASAN}

Penelitian pembelajaran mengonversi teks ekposisi ke dalam bentuk berpidato dengan menerapkan metode demonstrasi bermediakan video Soekarno dinyatakan efektif. Hasil penelitian menunjukkan bahwa nilai rata-rata tes akhir kelas eksperimen meningkat. Semula, nilai rata-rata kelas hanya mencapai 70,69. Lalu, setelah diberi perlakuan menjadi 79,38. Artinya, kelas eksperimen mengalami peningkatan sebesar 8,69\%. Sementara itu, nilai rata-rata tes akhir kelas kontrol pada tes awal hanya mencapai 71,84 . Kemudian, mengalami sedikit peningkatan di nilai tes akhir, yaitu 73,38. Artinya, peningkatan nilai rata-rata di kelas kontrol hanya $1,54 \%$. Dengan demikian, dapat dinyatakan bahwa hasil belajar kelas eksperimen lebih baik dari kelas kontrol.

Hasil penelitian tersebut menunjukkan terdapat peningkatan nilai pembelajaran berpidato secara resmi baik di kelas kontrol maupun di kelas eksperimen. Namun, peningkatan nilai di kelas eksperimen lebih tinggi daripada kelas kontrol. Hal ini dilatarbelakangi oleh penggunaan metode pembelajaran yang dapat meningkatkan antusiasme siswa dalam mengikuti proses pembelajaran. Pernyataan penulis ini ditegaskan oleh Djamarah dan Aswan (2010:91). Kedua ahli ini berpendapat bahwa metode demonstrasi membuat proses pengajaran lebih menarik [3].

Berkaitan dengan itu, perhitungan secara statistik menunjukan bahwa harga $\mathrm{t}$ hitung mencapai angka 2,73 sedangkan $t$ tabel mencapai angka 1,69. Dengan demikian, dapat dinyatakan bahwa $\mathrm{t}$ hitung $(2,73)>\mathrm{t}$ tabel $(1,69)$. Artinya, metode demonstrasi bermediakan video pidato Soekarno dapat meningkatkan nilai siswa secara efektif (signifikan) dalam pembelajaran mengonversi teks eksposisi ke dalam bentuk berpidato pada siswa kelas X SMA Negeri Lemahabang tahun pelajaran 2014/2015.

Keefektifan tersebut ditunjang beberapa faktor. Metode demonstrasi dapat membuat siswa konsentrasi mengamati proses demonstrasi yang ditampilkan. Tidak hanya itu, melalui penerapan ini menunjukkan kepada siswa tentang kekolerasian antara teori dan praktik. Kemudian, membuat siswa memahami materi berpidato secara mendalam. Hal ini selaras dengan Faturrohman dan Muhammad (2011:62) yang menyatakan bahwa metode demonstrasi bertujuan memprjelas pengertian konsep dan memperlihatkan cara melakukan sesuatu [4]. Sementara itu, media pembelajaran video pidato Soekarno. Turut memberikan konstribusi positif terhadap pembelajaran. Video tersebut mampu memberikan nuansa pembelajaran yang baru dan membuat siswa tertarik untuk mengamati proses demonstrasi. Media pembelajaran dapat membangkitkan keinginan, membangkitkan motivasi, dan membawa pengaruh psikologi kepada siswa[5].

Adapun proses pembelajaran mengonversi teks eksposisi ke dalam bentuk berpidato dengan menerapkan metode demonstrasi bermediakan video pidato berlangsung efektif. Siswa tampak aktif bertanya jawab dengan guru dan antusias mengamati jalannya proses demonstrasi. Hal ini ditandai dengan fokusnya siswa menyaksikan penayangan video pidato Soekarno tanpa mengeluarkan suara gaduh. Metode demonstrasi dan menstimulus siswa aktif mengamati maupun menyesuaikan antara teori dan praktik [6].Sementara itu, guru mampu mengelola kelas dengan baik, menjalankan setiap tahapan demonstrasi dengan apik, dan mampu menciptakan kekomunikatifan dalam pembelajaran. Selanjutnya, dari segi profil siswa. Pemerolehan nilai siswa dibagi menjadi tiga kategori, yaitu nilai tinggi (87-95), sedang (70-83), dan rendah (5466).Sehubungan dengan itu, dapat diketahui bahwa tiga aspek yang kurang diperhatikan siswa atau kurang dikuasai siswa, antara lain aspek ketepatan tempo 54,70\%, ketepatan intonasi $67,52 \%$, dan gerak-gerik. Sementara itu, aspek yang paling dikuasai siswa, yaitu aspek penyampaian struktur berpidato. Aspek tersebut memperoleh presentase $100 \%$ 
karena seluruh siswa menyampaikan struktur berpidato sesuai dengan kriteria yang tercantum dalam instrumen. Keberhasilan tersebut disebabkan oleh teknik berpidato dengan menggunakan teks yang sangat membantu siswa dalam menyampaikan struktur pidato secara resmi dengan sistematik. Teknik menggunakan naskah sering dipakai dalam pidato resmi [1]. Sementara itu, Rakhmat (2011:18) mengungkapkan bahwa keuntungan dari teknik menggunakan teks, yaitu kefasihan bicara dapat dicapai karena kata-kata sudah disiapkan dan hal-hal yang menyimpang dapat dihindari [8]..

\section{SIMPULAN}

\section{SIMPULAN}

Penerapan metode demonstrasi bermediakan video pidato Soekarno efektif meningkatkan kemampuan siswa kelas $\mathrm{X}$ MIIA 2 (kelas eksperimen) dalam berpidato. Hal ini ditunjukkan oleh nilai rata-rata tes akhir kelas eksperimen yang lebih besar dari nilai rata-rata tes akhir kelas kontrol $(79,51>72,97)$. Perhitungan uji t pun menunjukkan bahwa $t$ hitung $(2,47)>t$ tabel $(1,99)$ pada taraf signifikan 5\% dengan derajat kebebasannya mencapai angka 77 . Hal ini membuktikan bahwa adanya perbedaan signifikan antara nilai tes akhir eksperimen dan kelas kontrol. Kemudian, perhitungan uji efektivitas menyatakan $\mathrm{t}$ hitung $(2,73)>\mathrm{t}$ tabel $(1,69)$. Dengan demikian, dapat dinyatakan bahwa Ho ditolak sedangkan Ha diterima.

Hasil tersebut didukung oleh keoptimalan pembelajaran. Hasil observasi terhadap siswa dan guru menunjukkan bahwa kegiatan siswa dan guru dalam pembelajaran mengonversi teks eksposisi ke dalam bentuk berpidato dengan menerapkan metode demonstrasi bermediakan video pidato Soekarno sangat baik. Hal ini ditandai oleh presentase banyaknya siswa yang turut berpartisipasi aktif dalam melangsungkan setiap tahap pembelajaran. Lalu, guru pun menjelaskan materi dan tahap pendemonstrasian secara jelas serta detail. Selain itu, guru pun mampu menciptakan suasana yang komunikatif dan kondusif sehingga siswa tetap fokus mengikuti proses pembelajaran.

Adapun hasil pemerolehan nilai siswa dari setiap aspek yang dinilai dapat disimpulkan bahwa aspek ketepatan pelafalan mencapai nilai rata-rata $82,90 \%$, ketepatan tekanan mencapai $87,17 \%$, ketepatan tempo mencapai $54,70 \%$, ketepatan intonasi mencapai $67,52 \%$, sikap dan penampilan mencapai $92,30 \%$, gerak-gerik mencapai $77,77 \%$, dan penguasaan materi pidato mencapai 81,19\%, struktur penampilan berpidato mencapai $100 \%$. Dengan demikian, aspek penkemampuan pencapaian prestasi siswa dalam berpidato dikategorikan menjadi tiga, antara lain nilai terendah berada pada rentang nilai 54-67, nilai sedang pada rentang nilai $68-81$, dan nilai tertinggi berada pada rentang nilai 82-95. Kategori ini sendiri berlandaskan data hasil tes akhir siswa eksperimen yang terurut dalam tabel distribusi frekuensi siswa.Simpulan menyajikan ringkasan dari uraian mengenai hasil dan pembahasan, mengacu pada tujuan penelitian. Berdasarkan kedua hal tersebut dikembangkan pokok-pokok pikiran baru yang merupakan esensi dari temuan penelitian.

\section{DAFTAR PUSTAKA}

[1] Arsjad, Maidar G. dan Mukti U. S. 1993. Pembinaan Kemampuan Berbicara Bahasa Indonesia. Jakarta: Erlangga.

[2] Aqib, Zainal. 2013. Model-model, Media, dan Strategi Pembelajaran Kontekstual (Inovatif). Bandung: Yrama Widya.

[3] Djamarah, Syaiful Bahri dan Aswan Zain. 2010. Strategi Belajar Mengajar. Jakarta: Rineka Cipta.

[4] Fathurrohman, Pupuh dan M. Sobry Sutikno. 2011. Strategi Belajar Mengajar: Strategi Mewujudkan Pembelajaran Bermakna Melalui Penanaman Konsep Umum \&Islami. Bandung: PT Refika Aditama.

[5] Hamdani. 2011. Strategi Belajar Mengajar. Bandung: Pustaka Setia

[6] Huda, Miftahul. 2013. Model-model Pengajaran dan Pembelajaran Isu-isu Metodis dan Paradigmatis. Yogyakarta: Pustaka Pelajar.

[7] Musaba, Zulkifli. 2012. Terampil Berbicara Teori dan Pedoman Penerapannya. Yogyakarta: CV. Aswaja Pressindo.

[8] Rakhmat, Jalaluddin. 2011. Retorika Modern Pendekatan Praktis. Bandung: PT Remaja Rosdakarya.

[9] Sugiyono. 2013. StatistikauntukPenelitian. Bandung: Alfabeta 